Article

\title{
Lemon Extract Reduces Angiotensin Converting Enzyme (ACE) Expression and Activity and Increases Insulin Sensitivity and Lipolysis in Mouse Adipocytes
}

\author{
Shilpa Tejpal ${ }^{1}\left(\mathbb{D}\right.$, Alan M. Wemyss ${ }^{2}$ (D), Claire C. Bastie ${ }^{1, *}$ and Judith Klein-Seetharaman ${ }^{1,3, *}$ \\ 1 Division of Biomedical Sciences, Warwick Medical School, University of Warwick, Gibbet Hill, \\ Coventry CV4 7AL, UK; tejpalshilpa@gmail.com \\ 2 Department of Chemistry, University of Warwick, Gibbet Hill, Coventry CV4 7AL, UK; \\ A.Wemyss@warwick.ac.uk \\ 3 Department of Chemistry, Colorado School of mines, Golden, CO 80401, USA \\ * Correspondence: C.C.Bastie@warwick.ac.uk (C.C.B.); judithklein@mines.edu (J.K.-S.); \\ Tel.: +1-646-830-2622 (J.K.-S.)
}

Received: 26 June 2020; Accepted: 3 August 2020; Published: 6 August 2020

\begin{abstract}
Obesity is associated with insulin resistance and cardiovascular complications. In this paper, we examine the possible beneficial role of lemon juice in dieting. Lemon extract (LE) has been proposed to improve serum insulin levels and decrease angiotensin converting enzyme (ACE) activity in mouse models. ACE is also a biomarker for sustained weight loss and ACE inhibitors improve insulin sensitivity in humans. Here, we show that LE impacts adipose tissue metabolism directly. In 3T3-L1 differentiated adipocyte cells, LE improved insulin sensitivity as evidenced by a $3.74 \pm 0.54$-fold increase in both pAKT and GLUT4 levels. LE also induced lipolysis as demonstrated by a $16.6 \pm 1.2$ fold-change in pHSL protein expression levels. ACE gene expression increased $12.0 \pm 0.1$ fold during differentiation of 3T3-L1 cells in the absence of LE, and treatment with LE decreased ACE gene expression by $80.1 \pm 0.5 \%$ and protein expression by $55 \pm 0.37 \%$. We conclude that LE's reduction of ACE expression causes increased insulin sensitivity and breakdown of lipids in adipocytes.
\end{abstract}

Keywords: 3T3-L1 adipocytes; lipolysis; angiotensin converting enzyme (ACE) activity

\section{Introduction}

More than 2 billion people are classified as overweight or obese worldwide [1]. There are many approaches available to lose weight from surgical or drug-based interventions to different diet programs. The surgeries involve gastric bypass or gastrectomy, leading to massive weight loss in patients. However, patients need to be on a lifelong controlled diet and regular exercise. It comes with risks such as internal bleeding, pulmonary embolism and death [2,3]. Weight loss drugs, on the other hand, work by suppressing appetite or increasing metabolism [4]. However, these drugs are associated with side effects such as myocardial infarction and stroke [5]. The most common treatment of obesity involves dietary plans such as the Atkins Diet, the Mediterranean Diet, or the Keto-Diet, to name just a few. Generally, different diets fall into categories, such as low-carbohydrate diets, low-fat diets, caloric restriction, intermittent fasting, and alternate fasting. Many of these dietary interventions have been subjected to clinical trials to evaluate their effectiveness in promoting weight loss and improving markers of metabolic health, such as insulin sensitivity. For example, combining low-carbohydrate with high-protein intake has been shown to maintain low insulin levels and reduce the ratio between 
low-density lipoprotein (LDL) to high-density lipoprotein (HDL) [6,7]. However, the consumption of more calories originating from fat, especially saturated fatty acids, can potentially increase the risk of developing coronary heart disease [8]. Intermittent fasting can also increase insulin sensitivity and has been shown to protect against oxidative damage of proteins, lipids, and DNA [9]. Both, intermittent fasting and caloric restriction change serum insulin-like growth factor-1 and cortisol levels and improve immune function $[9,10]$. A type of calorie-restricted diet known as very low-calorie diets (VLCD) involve consumption of $<500 \mathrm{Kcal}$ per day and are hard to maintain [11]. They can cause mineral and vitamin loss during the early intervention period [12]. Individuals following very-low-calorie diets often experience headache, dizziness, fatigue, gastrointestinal problems, and nausea [13,14].

Lemon dieting is a VLCD diet in use since the 1940s, which provides 800 to 1000 kcal per day [15]. The program often consists of Neera syrup (a blend of maple and palm tree syrups) and lemon juice. The syrup is designed to have high amounts of minerals and trace elements. Therefore, the lemon detox program can provide higher minerals and vitamins than other VLCDs [15]. Instead of syrup, sugar can also be used, without the benefits of minerals, because the active weight loss ingredient is the lemon juice. However, the mechanisms by which lemon juice assists weight loss are not clear. Lemon juice is a known diuretic, and thus the mechanism may involve the angiotensin-renin system (RAS).

Benefits of plant bioactive compounds on metabolism have become a focus of multidisciplinary studies, and several plant extracts have been identified for the prevention of obesity [16]. Based on their nutritional value, such extracts may have physiological benefits and reduce the risk of chronic diseases $[17,18]$. For example, citrus fruit species are associated with decreased inflammation and reduced oxidative stress markers [19]. Other studies have found bergamot, grapefruit and orange juice to be associated with decreased total cholesterol, LDL and glucose concentration in humans [20-22]. Similar results have also been found in rats after lemon juice administration [23].

Obesity is associated with numerous co-morbidities such as type-2 diabetes, cardiovascular disease (CVD), metabolic syndrome, hypertension and several cancers [24-27]. The cellular mechanisms that are known to majorly contribute to these associations are related to insulin resistance and glucose uptake, lipolysis and regulation of blood pressure through RAS. Insulin resistance is defined as impaired sensitivity to insulin (normal or elevated), which mediates glucose disposal [28]. Expression levels of the glucose transporter type 4 (GLUT4), responsible for insulin-mediated glucose uptake [29], has been reported to be reduced in both, rodents and human with insulin resistance [30,31]. Even when GLUT4 is eliminated, specifically in adipose tissue, the absence of GLUT4 leads to a whole-body disturbance in glucose homeostasis, resulting in insulin resistance even in skeletal muscle and liver [32].

Maturation of adipocytes lead to increased expression of peroxisome proliferator-activated receptor $\gamma(\operatorname{PPAR} \gamma)$, fatty acid binding protein (FABP4), lipoprotein lipase (LPL), and adiponectin $[33,34]$. This results in an increased accumulation of triacylglyceride (TAG). Lipolysis is the breakdown of stored TAGs in adipocytes into glycerol and fatty acid (FA) [35]. The breakdown is regulated by different enzymes acting in an orderly fashion. Perilipin is one such enzyme and is located on the surface of lipid droplets (LD) in adipocytes. Its phosphorylation by protein kinase A (PKA) via cyclic adenosine monophosphate (cAMP) pathway leads to di- and triglyceride breakdown [36]. Hormone sensitive lipase (HSL), following PKA stimulation, translocates from the cytosol to LD surfaces leading to lipolysis [37]. Adipose triglyceride lipase (ATGL), TAG hydrolases and adiponectin are some other proteins involved in lipolysis.

The link between RAS and obesity has been known since 1968 [38]. It is, therefore, perhaps not surprising that profiling of blood proteins and steroid hormones revealed that angiotensin converting enzyme (ACE) concentration is a predictor of weight maintenance [39]. ACE is a zinc metallopeptidase involved in hydrolysis of angiotensin (ang) along with breakdown of bradykinin into inactive products [39-41]. ACE activity is a critical component of RAS responsible for the conversion of ang I to ang II [42]. Ang II is involved in decreased insulin sensitivity, increased reactive oxygen species generation, decreased glucose uptake, regulation of blood pressure and electrolyte balance [43]. Thus, ACE plays a key role in regulating blood pressure and electrolyte balance [44]. ACE inhibitors 
are widely used in the treatment and prevention of hypertension [45]. Increased production of ang II is associated with increased lipogenesis in human adipose cells [46]. It could induce differentiation leading to formation of mature adipocyte [47].

To better understand the mechanism of the beneficial effects of lemon juice on weight loss, the current study focuses on the effects of lemon extract (LE) on ACE expression, insulin sensitivity and fat accumulation in 3T3-L1 adipocytes.

\section{Materials and Methods}

\subsection{Reagents}

Dulbecco's modified Eagle's medium (DMEM), fetal bovine serum (FBS), new calf serum (NCS), Ham's F12, antibiotics, and other cell culture products were from Invitrogen and Thermo Fisher Scientific, Oxford, UK. AKT, pAKT, GLUT4, GADPH, perilipin, HSL and pHSL antibodies were from Cell Signaling Technology, London, UK. ACE 1 antibody was from Abcam Plc., Cambridge, UK. Polyvinylidene difluoride (PVDF) membranes used for Western blots were from Thermo Fisher Scientific, Oxford, UK. TriZol was from Invitrogen while Taqman gene expression assay kit for quantitative PCR and high capacity RNA to cDNA kit were from Applied Biosystems, Warrington, UK.

\subsection{Cell Culture}

3T3-L1 cells were maintained in DMEM/F12 medium supplemented with 10\% NCS and Penicillin-Streptomycin (Pen-Strep) antibiotic solution. They were differentiated as in [48]. Briefly, cells were plated and cultured to confluency (Day 0). They were then left for two days at confluence prior to addition of the differentiation medium, i.e., DMEM/F12 medium supplemented with $10 \%$ FBS, insulin, 3-isobutyl-1-methylxanthine (IBMX), dexamethasone and Pen-Strep antibiotic solution (Day 2). They were then treated for $48 \mathrm{~h}$ (until Day 4) with the differentiated medium. Following this, they were treated with maintenance medium (DMEM/F12 supplemented with $10 \%$ FBS and Pen-Strep solution) for 48 h (until Day 8).

\subsection{Preparation of Lemon Extract (LE)}

One lemon was squeezed into a $50 \mathrm{~mL}$ falcon tube. This solution was then frozen by placing the $50 \mathrm{~mL}$ falcon tube at $-20^{\circ} \mathrm{C}$ for $24 \mathrm{~h}$. The frozen solution was kept on dry ice for $2 \mathrm{~h}$ before freeze-drying. The solution was lyophilised overnight in an instrument named Alpha 2-4 LD plus made by Martin Christ Gefriertrocknungsanlagen $\mathrm{GmbH}$ (Osterode am Harz, Germany). The lyophilised powder was re-suspended in $10 \mathrm{~mL}$ of DMEM/F12. The $\mathrm{pH}$ was adjusted to 7.0 by adding sodium hydroxide.

\subsection{RNA Isolation and Gene Expression}

RNA was prepared using TriZol reagent. Real-time quantitative PCR was performed using Taqman expression assay for ACE as described by the supplier. Briefly, complementary DNA (cDNA) was synthesized from $100 \mathrm{ng}$ of total RNA with high capacity RNA to cDNA kit. Quantitative PCR was performed in Applied Biosystems 7500 Fast Real-Time PCR System instrument in the presence of Taqman gene expression assay and master mix. All experiments were done in 3 biological and experimental repeats.

\subsection{Protein Extraction}

Protein was extracted using radio immune precipitation (RIPA) lysis buffer complemented with a Protease inhibitor cocktail (Set V, Calbiochem, Dorset, UK) and a phosphatase inhibitor cocktail (P5726 (Sigma, Dorset, UK)). Cell lysates were vortexed every $2 \mathrm{~min}$ and kept on ice for $10 \mathrm{~min}$ before being centrifuged at $12,000 \mathrm{rpm}$ for $10 \mathrm{~min}$ at $4{ }^{\circ} \mathrm{C}$. Supernatants were collected and total proteins were quantified using a Modified Lowry assay (Thermo Scientific, Oxford, UK). All experiments were done in 3 biological and experimental repeats. 


\subsection{Western Blot Analysis}

Proteins $(30 \mu \mathrm{g})$ were separated on a $10 \%$ resolving and $4 \%$ stacking polyacrylamide-gel and electroblotted onto PVDF membranes. Blots were blocked with a 3\% BSA in Tris-buffered saline and $0.1 \%$ Tween-20 (TBST) for $60 \mathrm{~min}$ at room temperature and then incubated overnight at $4{ }^{\circ} \mathrm{C}$ with antibodies against pHSL (1:1000), ACE 1 (1:200), p (S473) AKT (1:1000), GLUT4 (1:1000) and GAPDH (1:1000) in TBST containing 1\% BSA. Blots were washed 3 times for 15 min with TBST and incubated with appropriate horse-radish peroxidase-conjugated secondary antibodies (1:10,000 in TBST) for $60 \mathrm{~min}$ at room temperature. Membranes were washed 3 times for $15 \mathrm{~min}$ in TBST and antigen-antibody complexes were visualized by chemiluminescence using an ECL kit (Thermo Scientific Fisher, Oxford, UK).

\subsection{ACE Inhibitory Activity Assay}

ACE inhibitory activity was measured by a fluorometric assay following the method of [49]. A potential ACE inhibitor would prevent conversion of Abz-GLY-PHe(NO2)-Pro to Abz-GLY by inhibiting ACE enzyme. A total of $50 \mu \mathrm{L}$ of $\mathrm{LE}(0,50,100$ and $500 \mu \mathrm{g} / \mathrm{mL})$ followed by $50 \mu \mathrm{L}$ ACE $(3 \mathrm{mU} / \mathrm{mL})$ solution was added in each well of a black 96 -well plate. The mixture was incubated at $37^{\circ} \mathrm{C}$ for $10 \mathrm{~min}$. A quantity of $200 \mu \mathrm{L}$ of Abz-GLY-PHe(NO2)-Pro in $150 \mathrm{mM}$ Tris base (pH 8.3) with $1.125 \mathrm{M} \mathrm{NaCl}$ was added to each well and fluorescence was measured at $360 \mathrm{nM}$ (excitation) and $430 \mathrm{~nm}$ (emission) for $\mathrm{t}=0$. The plate was then incubated for $30 \mathrm{~min}$ and reading was taken as mentioned above. \%inhibitory activity was calculated following the method in [50].

\subsection{Free Glycerol Release Assay}

Differentiated 3T3L1 adipocytes were pre-incubated with DMEM/F12 (without phenol red) for $2 \mathrm{~h}$ before being treated with LE or phosphate buffer saline (PBS) for $0,2,4,6$ and $24 \mathrm{~h}$. A $200 \mu \mathrm{L}$ aliquot was taken at $t=0,2,46$, and $24 \mathrm{~h}$. After $\mathrm{t}=24 \mathrm{~h}$, cells were lysed for protein extraction followed by protein quantification. Free glycerol amount was quantified using a free glycerol kit (Sigma, Dorset, UK). The amount of free glycerol was normalized by the amount of protein.

\subsection{Insulin Sensitivity Assay}

Cells were differentiated on a 12-well plate and starved overnight (Day 7) by addition of DMEM/F12 supplemented with Pen/Strep (FBS deprived) to the wells. On Day 8, they were incubated with $100 \mu \mathrm{g} / \mathrm{mL}$ of LE for $10 \mathrm{~h}$ or PBS (control) and then treated with $100 \mathrm{nM}$ of insulin for $15 \mathrm{~min}$ or PBS (negative control).

\subsection{Cell Viability Assay}

The cells were trypsinized as above and $50 \mu \mathrm{L}$ of cell suspension was added in an eppendorf tube. Equal parts of $0.4 \%$ trypan blue dye were added to the cell suspension and mixed by pipetting up and down. Place the cover slip on the hemocytometer and 10-20 $\mu \mathrm{L}$ of cell suspension on one side of the hemocytometer. The hemocytometer was placed on the stage of a light microscope and the cells were counted in each large corner. The percentage of viable cells were calculated by dividing the number of viable cells by the number of total cells and multiplying by 100 .

\subsection{Oil Red O Staining}

Cells were washed twice with PBS before being fixed in 10\% formalin (Sigma-Aldrich, Dorset, UK) for $60 \mathrm{~min}$. Cells were then washed with water and incubated with $60 \%$ isopropanol in water for $5 \mathrm{~min}$. Filtered Oil Red O solution ( 3 parts $3 \mathrm{mg} / \mathrm{mL}$ Oil Red O powder and 2 parts water) was added to the cells for $20 \mathrm{~min}$ at room temperature. The cells were then washed with water up to 5 times and covered with water to view under the microscope. For quantification, the water was removed and allowed to dry. The dye was eluted in 100\% isopropanol and incubated for $10 \mathrm{~min}$ with gentle shaking. 
The isopropanol was pipetted up and down several times ensuring that the dye was in the solution. Absorbance was taken at $500 \mathrm{nM}$ with $100 \%$ isopropanol as a blank.

\subsection{High-Performance Liquid Chromatography (HPLC)}

Agilent 1260 Infinity HPLC (Agilent Technologies, Stockport, UK) was used for analysis. LE was separated on a C-18 column $(250 \mathrm{~mm} \times 5 \mathrm{~mm} \times 4.6 \mathrm{~mm})$. The mobile phase consisted of $0.04 \%$ formic acid in water (A) and acetonitrile (ACN) in $0.04 \%$ formic acid (B). An injection volume of $50 \mu \mathrm{L}$ was used with the gradient conditions given in Table 1 . The column temperature was set at $25{ }^{\circ} \mathrm{C}$ and the sample absorbance at $278 \mathrm{nM}$ was monitored throughout each run.

Table 1. HPLC gradient program.

\begin{tabular}{cccc}
\hline Time (min) & A: Water & B: Acetonitrile & Flow Rate $(\mathbf{m L} / \mathbf{m i n})$ \\
\hline 0 & 95 & 5 & 1 \\
10 & 75 & 25 & 1 \\
20 & 60 & 40 & 1 \\
30 & 50 & 50 & 1 \\
35 & 5 & 95 & 1 \\
40 & 5 & 95 & 1 \\
50 & 95 & 5 & 1 \\
60 & 95 & 5 & 1 \\
\hline
\end{tabular}

\subsection{Mass Spectroscopy}

Following the optimisation of the HPLC conditions, different compounds in LE were identified using HPLC-MS. Data were acquired on the MaXis II Q-TOF instrument (Bruker AXS, Coventry, UK) coupled with Dionex 3000RS UHPLC and the column used was Agilent Zorbax C18, $100 \times 2.1 \mathrm{~mm}$ (Agilent Technologies, Stockport, UK). The mobile phase used was water (A) and acetonitrile (B) with $0.1 \%$ ammonium or formic acid, for measurements in positive or negative mode, respectively. The same gradient, as in HPLC, with a reduced flow rate of $0.2 \mathrm{~mL} / \mathrm{min}$ was used.

\subsection{Statistics}

Results are expressed as mean \pm S.D. Differences between cells or treatments were tested for statistical significance using the unpaired Student's t test.

\section{Results}

\subsection{Lemon Extract Decreases ACE Gene and Protein Expression as Well as ACE Enzymatic Activity}

A significant $(p<0.002)$ and robust $(12.00 \pm 0.05$-fold $)$ increase in ACE gene expression was observed during 3T3L1 adipogenesis (Figure 1A). Incubation of mature differentiated 3T3L1 adipocytes with total LE $(100 \mu \mathrm{g} / \mathrm{mL})$ resulted in a significant reduction in ACE gene expression, which was reduced by $80.0 \% \pm 0.5 \%$ after $10 \mathrm{~h}$ (Figure $1 \mathrm{~B}$ ). Differentiated 3T3-L1 cells were treated with LE doses of 50,100 and $500 \mu \mathrm{g} / \mathrm{mL}$. There was no significant change in ACE protein expression within the 3 doses (Figure 1, and for individual repeats see Figure S1 and Table S1) used, likely because $50 \mu \mathrm{g}$ was already the maximum effect on the protein expression (Figure 1C). However, there was a 40.0-55.0 $\pm 0.4 \%$ $(p=0.01)$ reduction in protein expression compared with untreated cells (Figure 1D). This was tightly correlated with ACE reduced activity (15\% up to 87\%) with increasing concentrations of LE (Figure 1E). ACE activity was quantified by measuring the conversion of ACE substrate Abz-GLY-Phe(NO2)-Pro into Abz-GLY product. Consistent with previous studies [23], it was observed that LE prevented this reaction, demonstrating inhibition of ACE activity. 
A

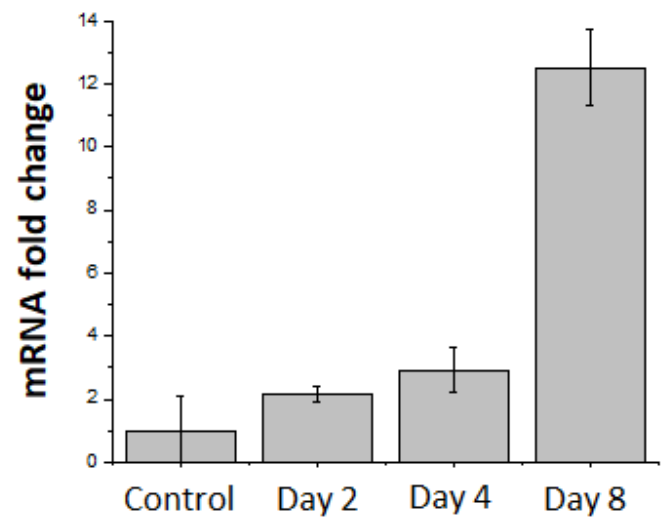

C

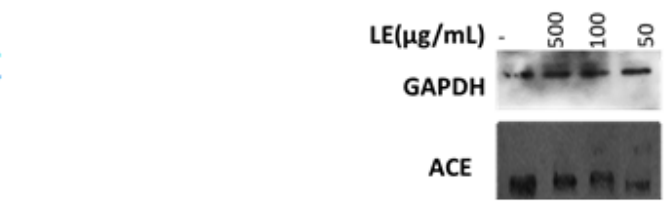

D

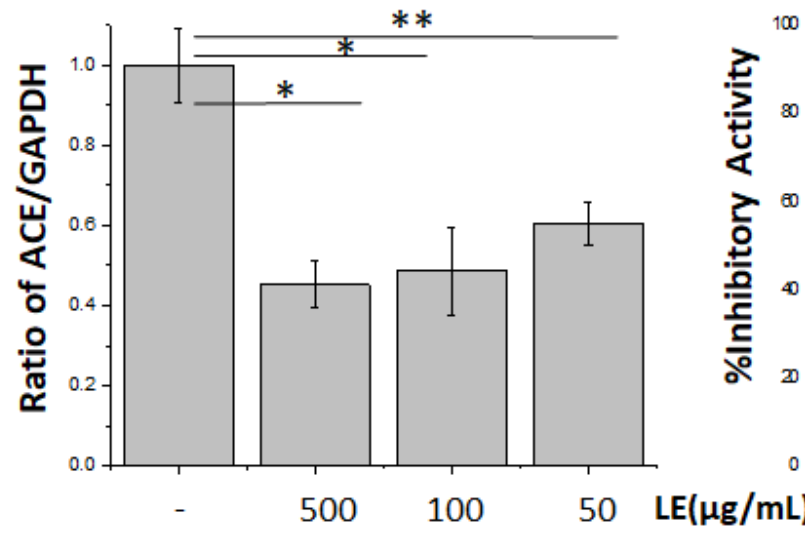

B

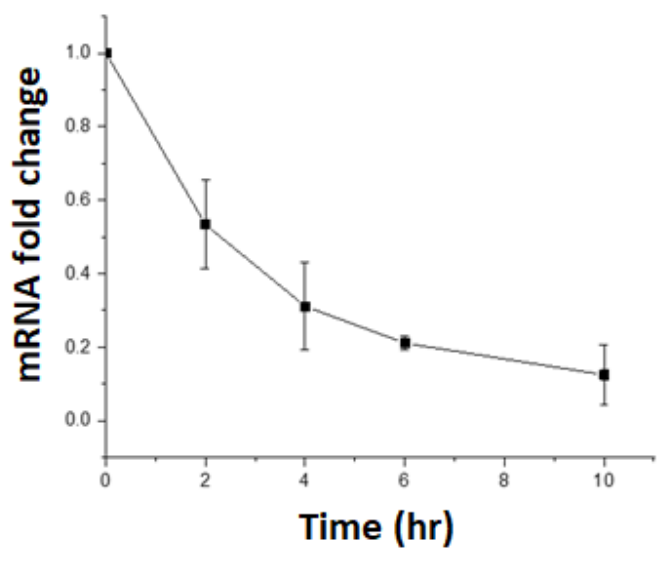

$\mathrm{E}$

Figure 1. Total lemon extracts (LE) decrease angiotensin converting enzyme (ACE) expression and activity. (A) ACE mRNA expression levels were quantified at the indicated days during 3T3L1 adipocyte differentiation. $n=3$ independent experiments, $p<0.001$. (B) Fully differentiated 3T3L1 adipocytes were treated or not with LE $(100 \mu \mathrm{g} / \mathrm{mL})$ for the indicated times and ACE mRNA expression levels were quantified. $n=3$ experiments, $p<0.05$. (C) 3T3L1 differentiated adipocytes were incubated with 50,100 or $500 \mu \mathrm{g} / \mathrm{mL}$ of LE for $10 \mathrm{~h}$ on day 8 . ACE and GAPDH protein expression were assessed by immunoblotting. GAPDH was used as internal control. $n=3$. (D) Signal quantification of ACE and GAPDH immunoblots (E) LE inhibitory effects on ACE activity. Cells were treated with LE (50, 100 and $500 \mu \mathrm{g} / \mathrm{mL}$ ) and conversion of Abz-GLY-PHe(NO2)-Pro to Abz-GLY was quantified as described in methods. $n=3$. ${ }^{* *}$ significant at $p=0.01$ and * significant at $p=0.05$.

\subsection{Lemon Extract Decreases Lipid Droplet Numbers in 3T3-L1 Adipocytes}

Peroxisome proliferator-activated receptor gamma (PPAR $\gamma)$ and Fatty Acid-Binding Protein 4 (FAPB4) are known markers of late adipose differentiation [33]. Differentiated mature adipocytes treated with LE showed similar PPAR $\gamma$ and FABP4 gene expression compared to control untreated adipocytes, suggesting that LE treatment was not affecting the adipogenesis process (Figure 2A). However, visualization of adipocytes by Oil red O staining showed that LE-treated adipocytes displayed a drastic reduction in lipid droplet numbers compared to control untreated cells (Figure 2B). The number of Oil red O stained cells after a $24 \mathrm{~h}$ treatment with LE was decreased by up to $90 \%$ $(p=0.034)$ (Figure 2C). Quantification of the extent of staining by UV-vis spectroscopy showed a significant decrease $(p<0.001)$ in absorbance for LE-treated cells, compared to control cells (Figure 2D). This showed that LE does not affect the differentiation process but leads to decreased fat deposits in the 
cells as observed through the staining of the adipocytes. A study comparing effects of ACE inhibitors on PPAR $\gamma$ stimulation found that affinity to PPAR $\gamma$ was highest for telmisartan followed by lisinopril and valsartan at a concentration of $463,2.9$ and $6.2 \mu \mathrm{M}$, respectively [51]. It was thought that 1-10 $\mu \mathrm{mol}$ of telmisartan activates PPAR- $\gamma$ but the concentration may be too small to exert an additional benefit on glucose metabolism [52]. The concentrations of LE used in the experiments may be insufficient to stimulate a change in PPAR $\gamma$ levels although a change in fat deposition was observed.

A
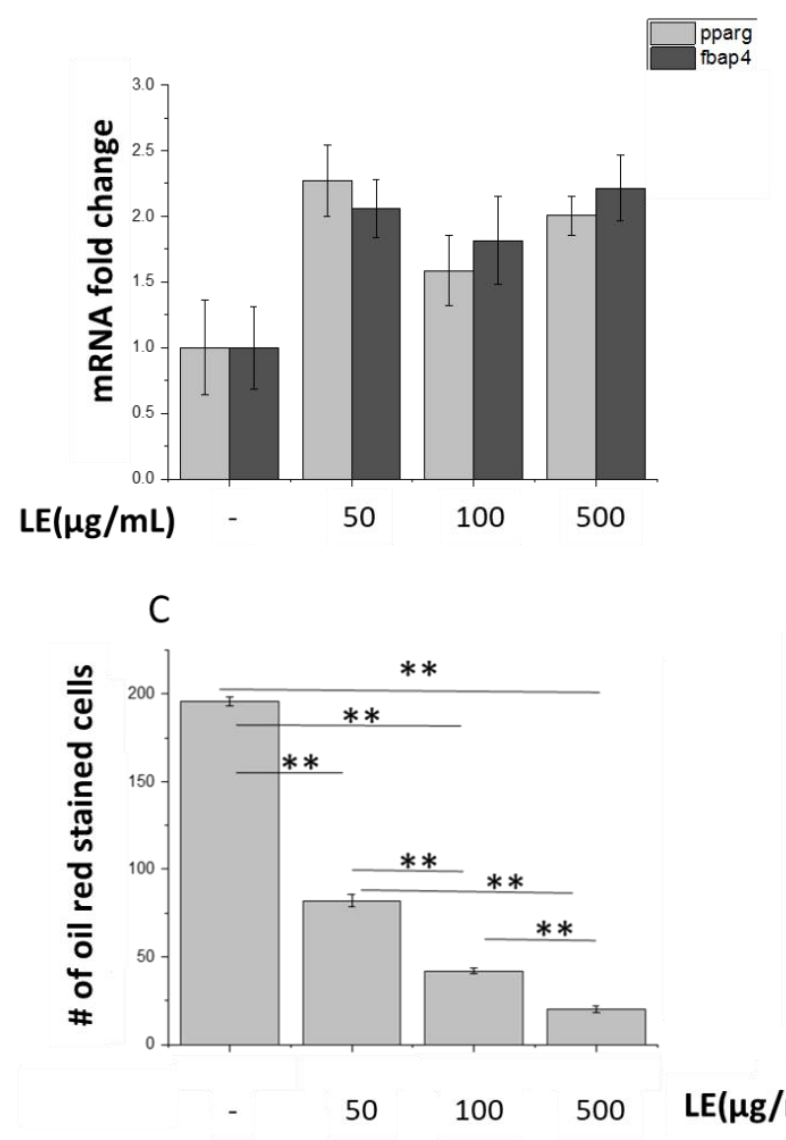

B

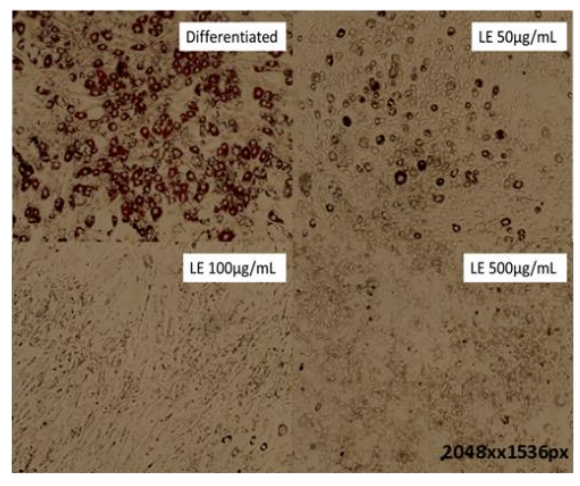

D

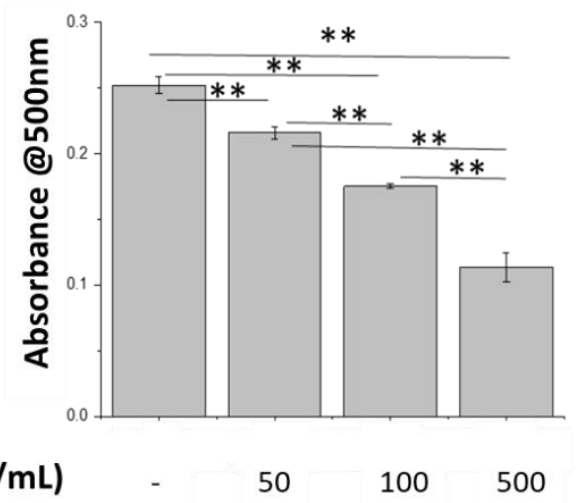

Figure 2. Lemon extract (LE) decreases lipid droplets in 3T3-L1 adipocytes. (A) PPAR $\gamma$ and FABP4 mRNA expression levels were quantified in adipocytes treated with and without LE $(100 \mu \mathrm{g} / \mathrm{mL})$ for 8 days. $n=3$. (B) Lipids were visualized using Oil Red staining. Images are representative of 3 experiments. (C) Staining was quantified using ImageJ by calculating number of oil red stained cells in the section shown in (B), ${ }^{* *}$ significant at $p=0.01$. (D) Quantified oil red stain in treated and untreated adipocytes, ${ }^{* *}$ significant at $p=0.01$.

\subsection{Stimulation of Lipolysis by Lemon Extract}

Hormone Sensitive Lipase (HSL) is a known marker for mobilization of lipids through lipolysis [35]. To understand the apparent decrease in lipid droplets, protein expression for pHSL was analysed. An increase in phosphorylation levels of HSL in response to increasing doses of LE was found. A 2.6, 6.5 and 16.6 fold change in pHSL levels in LE-treated differentiated cells was observed in comparison to control untreated differentiated cells (Figure 3A,B) after $10 \mathrm{~h}$ of treatment. To further test the hypothesis that the decrease in lipid droplet numbers was due to lipolysis, a free glycerol release assay was performed on mature adipocytes at $\mathrm{t}=2,4,6,10$ and $24 \mathrm{~h}$ (Figure 3C) with different doses of LE. Hydrolysis of triglycerides through lipolysis lead to the release of free glycerol and free fatty acids (FFA). Free glycerol amounts of 23.08, 29.19 and $39.22 \mu \mathrm{g}$ per $\mathrm{mg}$ of total protein was released after a 24-h treatment of 3T3-L1 cells with LE doses of 50, 100 and $500 \mu \mathrm{g} / \mathrm{mL}$, respectively. At a LE dose of 
$500 \mu \mathrm{g} / \mathrm{mL}$, a 4.02-fold higher release of free glycerol at $\mathrm{t}=2 \mathrm{~h}$ was observed in comparison to $\mathrm{t}=0 \mathrm{~h}$ (Figure 3C). A similar increase ( 3.5-4.2 fold) was seen at $t=10$ and $t=24 \mathrm{~h}$ for the 50 and $100 \mu \mathrm{g} / \mathrm{mL}$ LE doses. To confirm that LE did not lead to cell death, cell viability was assayed. The cells were treated with LE for $72 \mathrm{~h}$ and on an average $90.0 \pm 0.5,92.1 \pm 0.2$ and $91.9 \pm 0.1 \%$ were viable even after $72 \mathrm{~h}$ (Figure 3D).
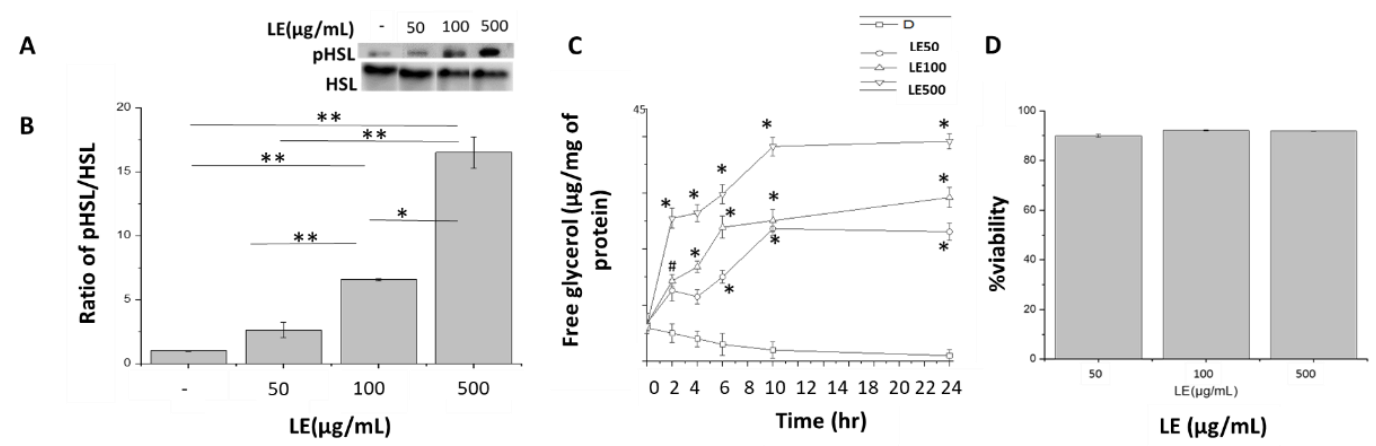

Figure 3. Stimulation of lipolysis by lemon extract (LE). (A) Blot for protein expression for pHSL and HSL in untreated differentiated cells, differentiated cells treated with LE dose of 50, 100 and $500 \mu \mathrm{g} / \mathrm{mL}$. (B) Quantified protein expression for pHSL and HSL in untreated differentiated cells and differentiated cells treated with LE, at a dose of 50, 100 and $500 \mu \mathrm{g} / \mathrm{mL}$. (C) Free glycerol release from treated and untreated cells after $\mathrm{t}=0,2,4,6,10$ and $24 \mathrm{~h} .{ }^{*}$ significant at $p=0.01$ and \# significant at $p=0.05$. (D) Differentiated cells alone, differentiated cells treated with LE, at a dose of $50 \mu \mathrm{g} / \mathrm{mL}$ (LE50), differentiated cells treated with LE, at a dose of $100 \mu \mathrm{g} / \mathrm{mL}$ (LE100) and differentiated cells treated with LE, at a dose of $500 \mu \mathrm{g} / \mathrm{mL}$ (LE500) (D) Cell viability in the presence of LE, at a dose of 50, 100 and $500 \mu \mathrm{g} / \mathrm{mL} .{ }^{* *}$ significant at $p=0.01$ and ${ }^{*}$ significant at $p=0.05$. For $(\mathbf{C})$

\subsection{Lemon Extract Increases Insulin Sensitivity}

Protein Kinase B (AKT) is an important signaling molecule in the insulin pathway [53]. The insulin phosphorylation site Ser473 of AKT was more phosphorylated in control cells after insulin stimulation, with no effects on total AKT expression. Interestingly, LE incubation accentuated the insulin response, evidenced by a 3.74-fold increase in AKT Ser473 phosphorylation levels (compared to control; Figure 4A,B). A similar response was observed for GLUT4 expression, which was also increased in LE-treated cells (compared to untreated cells; Figure 4C,D).

A

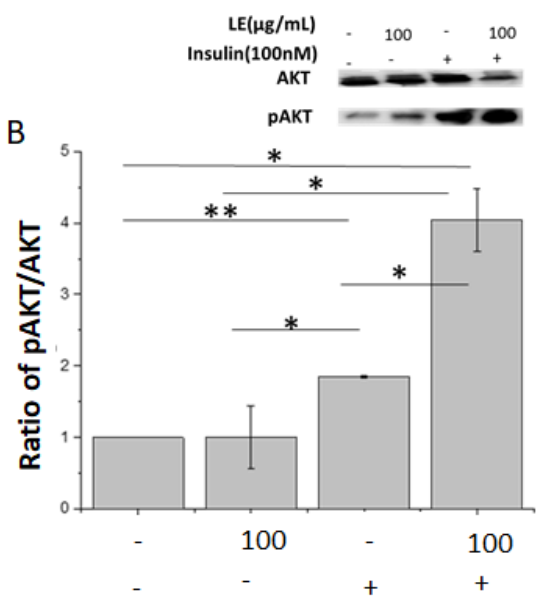

C

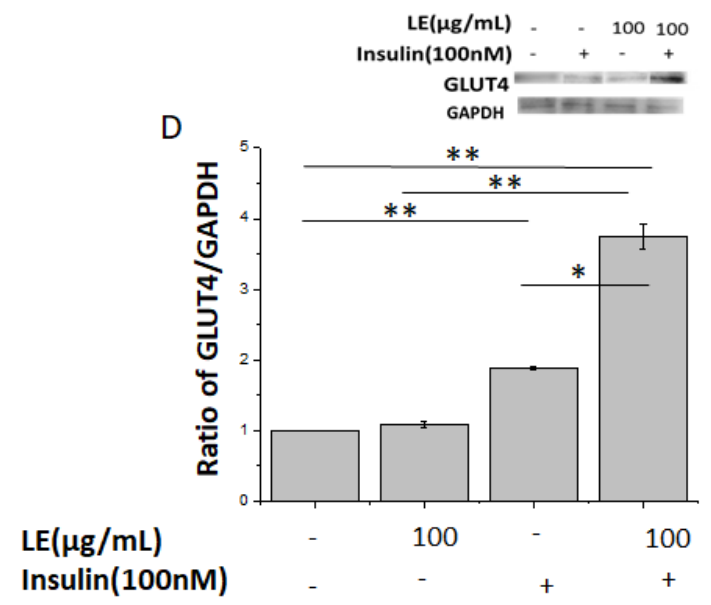

Figure 4. Lemon extract (LE) increases insulin sensitivity in differentiated adipocytes. (A) 3T3L1 differentiated adipocytes were incubated with or without LE for $10 \mathrm{~h}$ before being treated with $100 \mathrm{nM}$ insulin for $10 \mathrm{~min}$. Total AKT and phosphorylated AKT (pAKT) on Ser473 protein levels were assessed 
by immunoblotting in untreated differentiated cells (D), differentiated cells treated with LE (D+LE), differentiated cells treated with $100 \mathrm{nM}$ insulin $(\mathrm{D}+\mathrm{I})$ and differentiated cells treated with LE and $100 \mathrm{nM}$ insulin (D+LE+I). $n=3, p<0.05$. (B) Signal quantification of protein expression for AKT and pAKT in D (untreated differentiated cells), differentiated cells treated with LE (D+LE), differentiated cells treated with $100 \mathrm{nM}$ insulin (D+I) and differentiated cells treated with LE and $100 \mathrm{nM}$ insulin $(\mathrm{D}+\mathrm{LE}+\mathrm{I})$. (C) 3T3L1 differentiated adipocytes were incubated with or without LE for $10 \mathrm{~h}$ before being treated with $100 \mathrm{nM}$ insulin for $10 \mathrm{~min}$. GLUT4 and GAPDH (loading control) were assessed by immunoblotting in untreated differentiated cells (D), differentiated cells treated with LE (D+LE), differentiated cells treated with $100 \mathrm{nM}$ insulin (D+I) and differentiated cells treated with LE and $100 \mathrm{nM}$ insulin (D+LE+I). $n=3, p<0.05$. (D) Quantified protein expression for GLUT4 and GADPH in untreated differentiated cells (D), differentiated cells treated with LE (D+LE), differentiated cells treated with $100 \mathrm{nM}$ insulin (D+I) and differentiated cells treated with LE and $100 \mathrm{nM}$ insulin (D+LE+I).

** significant at $p=0.01$ and * significant at $p=0.05$.

\subsection{Identification of Lemon Constituents by HPLC and HPLC/MS}

Having determined the effects of LE on adipocyte lipid utilization, further investigation was conducted to identify the compounds in the extract that could have been involved in the LE-induced increased lipolysis. HPLC-MS has been routinely used to identify active components in plant extracts [54,55]. HPLC measurements were first conducted to optimise the conditions for column separation of LE constituents. The chromatograms generated from these measurements are shown in Figure 5. The optimised conditions were run three times to ensure reproducibility of the spectrum. Then, high-resolution HPLC-MS was performed to obtain the molecular formulas of the different compounds in the extract. A total of 16 compounds were identified (see Table 2) through the mass/charge $(\mathrm{m} / \mathrm{z})$ ratios of their molecular ions $\left([\mathrm{M}-\mathrm{H}]^{-}\right)$and fragments [56]. This was compared to compounds in the PubChem database for identification. Citric acid was identified at a retention time (RT) of $1.3 \mathrm{~min}$. Limonoids such as Nomilinic acid-17-Oglucoside, Nomilinic acid-4-Oglucoside and Limonin glucoside were found at $\mathrm{RT}=13.3,14.7$ and $13.1 \mathrm{~min}$, respectively. A mixture of flavonoids, Kaempferol acetyl dihexoside, Diosmetin-6, 8-di-C-hexoside, Diosmetin-7-O-rutinoside, Chrysoeriol 7-rutinoside, Chrysoeriol -7-O-neohesperidoside and Apigenin-6,8-di-C-glucoside, were also observed. A subfamily of flavonoids that contains a 3-hydroxyflavone backbone is referred to as flavonols. 6,8-C, CDiglucosyldiosmetin, Neodiosmin, Eriodictyol and Apigenin were the different flavonols present in our LE.

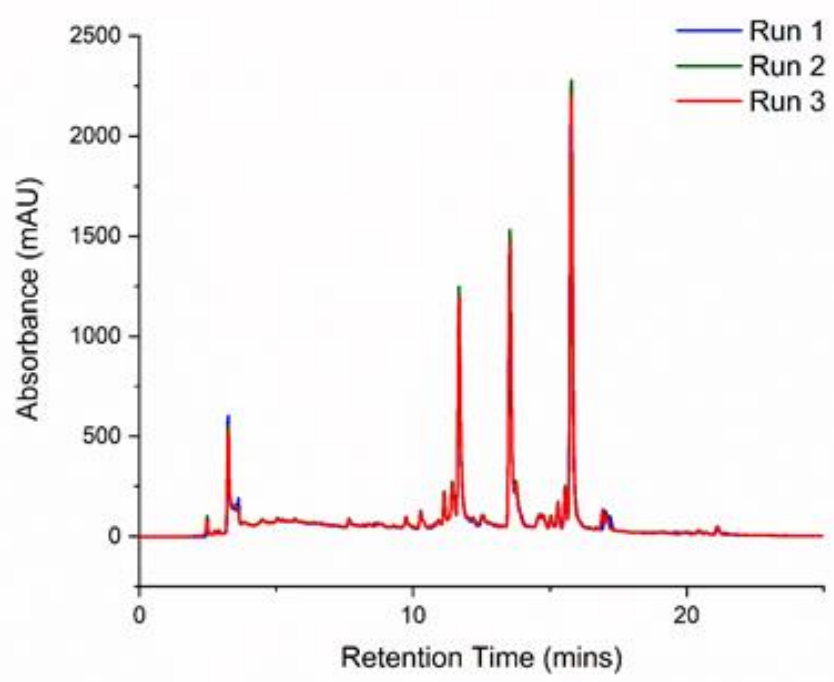

Figure 5. HPLC chromatogram of lemon extract. The extract was run on a C18 column with a mobile phase of water and acetonitrile; repeated thrice. 
Table 2. List of compounds found in lemon extract using HPLC/MS.

\begin{tabular}{|c|c|c|c|c|c|}
\hline RT (min) & [M-H]- & Mol. Formula & MS Fragments (m/z) & Name & Class \\
\hline 1.3 & 191.02 & $\mathrm{C}_{6} \mathrm{H}_{7} \mathrm{O}_{7}$ & 133,111 & (iso)citric acid & Organic acid \\
\hline 5.9 & 771.201 & $\mathrm{C}_{33} \mathrm{H}_{39} \mathrm{O}_{21}$ & $\begin{array}{c}695,547,415,375 \\
353,285,191\end{array}$ & Kaempferol-Osophoroside-Oglucoside & $\begin{array}{l}\text { Flavonol acylated } \\
\text { glycoside }\end{array}$ \\
\hline 13.1 & 711.28 & $\mathrm{C}_{34} \mathrm{H}_{47} \mathrm{O}_{16}$ & $693,549,341$ & Nomilinic acid-17-O-glucoside & Limonoid \\
\hline 14.7 & 693.2775 & $\mathrm{C}_{34} \mathrm{H}_{45} \mathrm{O}_{15}$ & $531,443,341$ & Nomilinic acid-4-Oglucoside & Limonoid \\
\hline 2.6 & 651. & $\mathrm{C}_{29} \mathrm{H}_{31} \mathrm{O}_{17}$ & $507,417,341$ & Kaempferol acetyl dihexoside & Flavonoid-3-o-glycosides \\
\hline 13.1 & 649.2513 & $\mathrm{C}_{32} \mathrm{H}_{41} \mathrm{O}_{14}$ & 413,341 & Limonin glucoside & Limonoid \\
\hline 8.9 & 625.17 & $\mathrm{C}_{28} \mathrm{H}_{33} \mathrm{O}_{16}$ & 383,312 & $\begin{array}{l}\text { Diosmetin-6, 8-di-C-hexoside } \\
\text { (Lucenin-2,4'-methyl ether) }\end{array}$ & flavonoid-7-o-glycosides \\
\hline 2.3 & 623.1622 & $\mathrm{C}_{28} \mathrm{H}_{31} \mathrm{O}_{16}$ & $605,533,503,579,443$ & 6,8-C, CDiglucosyldiosmetin isomer & C-flavone glycoside \\
\hline 2.7 & 623.1565 & $\mathrm{C}_{28} \mathrm{H}_{31} \mathrm{O}_{16}$ & $605,533,503,413,329$ & C,CDiglucosyldiosmetin & C-Flavone glycoside \\
\hline 14.9 & 609.1825 & $\mathrm{C}_{28} \mathrm{H}_{33} \mathrm{O}_{15}$ & 301.07 & Diosmetin-7-O-rutinoside (diosmin) & Flavonoid-7-o-glycosides \\
\hline 15.7 & 609.1824 & $\mathrm{C}_{28} \mathrm{H}_{33} \mathrm{O}_{15}$ & & Chrysoeriol 7-rutinoside & flavonoid-7-o-glycosides \\
\hline 13.6 & 607.1668 & $\mathrm{C}_{25} \mathrm{H}_{31} \mathrm{O}_{15}$ & 299,284 & $\begin{array}{c}\text { Diosmetin 7-O-neohesperidoside } \\
\text { Neodiosmin }\end{array}$ & Flavone \\
\hline 14.7 & 607.1668 & $\mathrm{C}_{25} \mathrm{H}_{31} \mathrm{O}_{15}$ & $299,283.8$ & Chrysoeriol-7-O-neohesperidoside & Flavonoid-7-o-glycosides \\
\hline 13.3 & 595.1668 & $\mathrm{C}_{27} \mathrm{H}_{31} \mathrm{O}_{15}$ & $\begin{array}{l}505,457,427,421 \\
409,391,379,355, \\
337,325,307,295\end{array}$ & Apigenin-6,8-di-C-glucoside & Flavonoid \\
\hline 13.0 & 287.0556 & $\mathrm{C}_{15} \mathrm{H}_{11} \mathrm{O}_{6}$ & $151,135,125,107$ & (2S)-Eriodictyol & Flavone \\
\hline 36.7 & 269.24 & $\mathrm{C}_{17} \mathrm{H}_{37} \mathrm{O}_{2}$ & $225,201,151$ & Apigenin & Flavone \\
\hline
\end{tabular}

\section{Discussion}

The link between lemon juice dieting and insulin sensitivity has been established in humans previously: overweight women following a lemon detox diet (lemon juice with a mixture of maple and palm syrup) for 7 days showed reduced body fat and increased insulin sensitivity [15]. Here, we set out to understand the mechanisms underlying this finding. We demonstrate for the first time that LE treatment influences ACE gene expression levels in adipocytes. Specifically, 3T3-L1 adipocytes treated with LE decreased mRNA expression by $\sim 80 \%$ after $10 \mathrm{~h}$ of exposure. We show that this process is accompanied by differentiation to mature adipocytes. This supports previous studies showing that higher ACE expression is related to increased adiposity and fat deposition in both, murine and human studies $[57,58]$. Increased production of ang II in adipose tissue has been observed in diet-induced obesity models [59]. The inhibitory effect of LE implies that it has the potential to act as an ACE inhibitor. Lemon and lime juice both inhibit ACE activity in a dose-dependent manner in mouse models [23]. 3T3-L1 cells also showed improved insulin sensitivity after treatment with LE, evidenced by increased p-AKT and GLUT4 levels. Several studies testing citrus fruits have found decreased insulin stimulated glucose uptake and improved glycemia and HbA1c levels [60,61].

Expression of GLUT4 and proteins involved in lipid breakdown showed coordinated upregulation in LE-treated adipocytes. In the LE-treated cells, there was an increase in free glycerol release along with perilipin and pHSL protein expression. It is well-established that these proteins and glycerol are a result of lipid breakdown [62,63]. Phosphorylation of HSL can also occur due to increased cAMP level activating a PKA pathway that is known to be involved in insulin signaling [64,65]. With these changes, it can be said that different compounds in our LE might be acting through PI3K/AKT pathway and could be used to treat obesity.

Mice with deletion of ACE (ACE-/-) have a reduced fat mass and improved glucose tolerance [66]. Diet-induced obesity in mice has been found to be reversed by ACE inhibitors [67]. Treatment with ACE inhibitor also decreases circulating leptin and insulin levels in rats [68]. A 12-week treatment of C57BL/6J mice, afflicted by diet-induced obesity, with an ACE inhibitor captopril increased peroxisome proliferator-activated receptor-g coactivator-1a, long-chain acyl-CoA dehydrogenase and HSL expression levels [67]. Another study analysing the long-term effects of ACE inhibitor enalapril in normotensive adult Wistar rats showed decreased ACE activity and enhanced the expression of adiponectin, HSL, fatty acid synthase and superoxide dismutase [69]. These findings support a potential link between ACE and HSL. Angiotensin inhibitors or ang II receptor inhibition augments natriuretic 
peptide (NP) levels [70]. Natriuretic peptides are a family of peptides that have diuretic, natriuretic, and vasodilator properties [71]. Atrial NP (ANP) induced lipolysis in human adipocytes is associated with a cGMP-dependent pathway that enhances HSL serine phosphorylation [72,73]. The guanylyl cyclase inhibitor LY-83583 inhibits ANP-mediated lipolysis and HSL phosphorylation in human adipocytes. Inhibition of ACE enzyme and ang II receptor improved ANP levels as well as cGMP levels in plasma and urine in a rat model of shunt-induced heart failure [74]. NPs have recently been shown to increase browning of adipocytes [75], which is usually associated with increased fat utilization and increased insulin sensitivity [76,77] and increased HSL phosphorylation [78]. The changes in pHSL levels seen in our study could be a result of increased NP levels or due to activation of PKA signaling involved in insulin sensitivity. Further studies are needed to identify association of LE and NP levels.

Combining the different effects of LE, we here establish that LE alters the metabolism in mature adipocytes. Our study provides mechanistic support for the conclusion that LE's effects on ACE expression and improved insulin sensitivity are related to each other. Moreover, LE acting as a potential ACE inhibitor could directly induce lipid breakdown (Figure 6). We have previously shown that ACE can act as a predictor for weight loss over a $24 \mathrm{~h}$ period [79]. Determining the effects of LE open doors for the use of lemon as an ACE regulator.

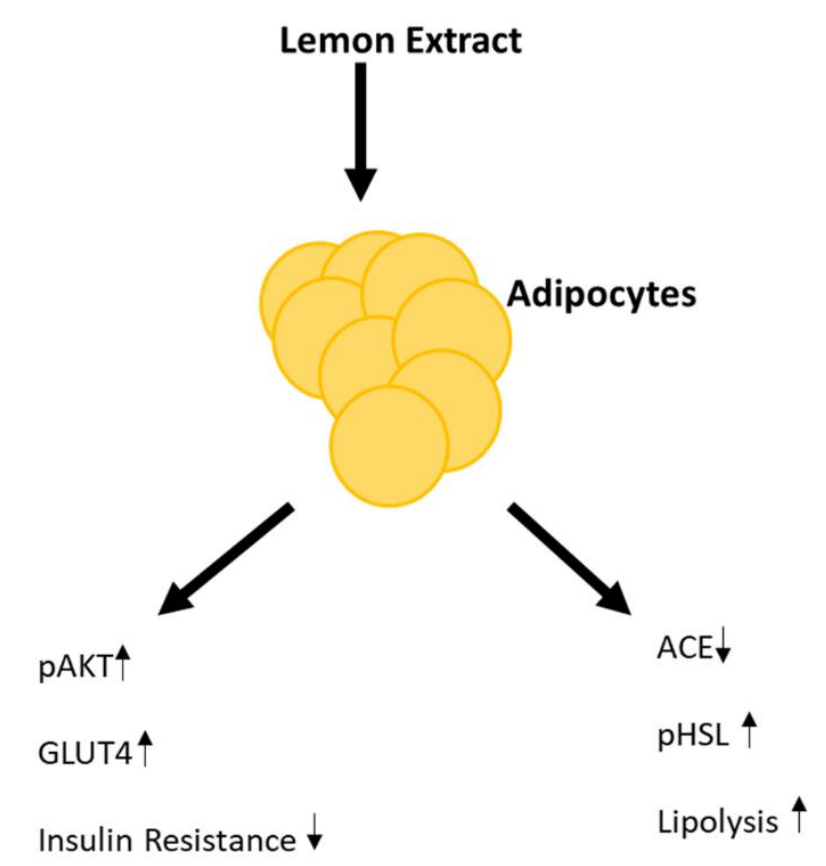

Figure 6. Proposed mechanism in which lemon extract (LE) induces insulin sensitivity and lipolysis in adipocytes. $\uparrow$ - upregulation and $\downarrow$ - downregulation.

Similar to the experiments with rats, a study conducted with humans involving drinking lemon juice found decreased body fat, waist-hip ratio and high-sensitive C-reactive protein (hsCRP) in serum [15]. Similar results were obtained with other citrus fruits such as orange juice, bergamot extract and grapefruit, which all have beneficial effects on lipid variables. Drinking orange juice every day lowered concentrations of LDL and the LDL/HDL ratio [22]. Another study involving supplementation of every meal with grapefruit decreased body weight [21].

To begin narrowing down what are possible ingredients in LE responsible for the effects observed in this study, we conducted HPLC/MS analysis of the LE we prepared. We were able to identify 16 different compounds. A few of these or closely related compounds have been studied with respect to their biological activities. Rat plasma triacylglycerol level reduced after oral administration of mixture of Chrysoeriol-7-O-neohesperidoside and apigenin prepared from the leaves of Salix matsudana [80]. Mouse fed with $0.15 \%$ Kaempferol, prepared from unripe soybean leaves, had a reduced body weight, 
blood glucose due to down regulation of PPAR $\gamma$ and sterol regulatory element-binding protein expression in liver [81]. Kaempferol is thought to improve glucose uptake in rats through PI3K/AKT pathway [82]. In our study, we found increase in insulin sensitivity through AKT pathway showing that Kaempferol acetyl dihexoside and Kaempferol-Osophoroside -Oglucoside could be the active compounds in our extracts.

The commonly studied flavonoid in citrus fruits studies are naringin (Flavonoid-7-o-glycosides), hesperidin (flavonoid glycoside) and nobiletin [60]. Naringin and nobiletin were not identified in our extract through MS technique. Different diosmetin species (such as Diosmetin-6, 8-di-C-hexoside, 6,8-c-c diglucosyldiosmetin isomer, c-c diglucosyldiosmetin, diosmetin 7-O-neohesperidoside and diosmetin-7-O-rutinoside) found in our extract are derived from hydrogenation of hesperidin. These molecules inhibit the accumulation of triglycerides, increase HDL and decrease VLDL-TG sections [83,84]. Naringenin has anti-inflammatory properties and promotes insulin sensitivity $[83,85]$. Mouse model studies found that supplementation of a high-fat, cholesterol-containing diet with naringenin attenuated weight gain and adiposity, enhanced insulin signaling, lowered plasma lipids and prevented systemic inflammation [86]. It also reduced adipose tissue mass [86]. Hesperidin decreases plasma and hepatic cholesterol and triacylglycerol by inhibiting the hepatic enzymes [84,87]. Type-2 diabetic animals supplemented with hesperidin improved hyperlipidemia and hyperglycemia and enhanced hepatic and adipocyte PPAR $\gamma$ protein expression [88]. Healthy volunteers consuming hesperidin for 4 weeks showed a reduction in cytokines and inflammatory markers in circulation [89-91]. Limonoids are highly oxygenated triterpenoid compounds present in citrus species and are responsible for bitterness in citrus juices [92]. The major types of limonoids are limonin and nomilin. We observed a mixture of limonoids in our extract (see Table 1). Male C57BL/6J mice fed a high-fat diet (HFD) supplemented with $0.2 \% w / w$ nomilin for 77 days had lower body weight, serum glucose and insulin, and enhanced glucose tolerance [93]. These changes were associated with TGR5 signaling and nomilin has been identified as a novel agonist for TGR5 [93]. TGR5 is a novel G protein-coupled receptor that promotes the elevation of intracellular cAMP levels in adipose tissue [94]. Eriodictyol supplementation in mice fed with a high-fat diet for 16 weeks improved insulin resistance by suppressing hepatic gluconeogenesis, enhancing glucose utilization, and modulating the production and release of gastric inhibitory polypeptide and glucagon-like peptide-1 [95]. It also significantly downregulated the expression of lipogenesis-related genes. Thus, it is likely that several of the individual compounds in LE might work in synergy to create the beneficial effects seen in our study.

\section{Conclusions}

The LE-dependent fat breakdown properties observed in mature adipocytes rationalizes its use as dietary intervention. The link between LE and ACE expression levels and LE as an ACE inhibitor also provides a mechanism based upon which LE is not only useful in the management of obesity but could also be beneficial in the management of cardiovascular diseases.

Supplementary Materials: The following are available online at http://www.mdpi.com/2072-6643/12/8/2348/s1, Figure S1: Western blot of ACE and GADPH, Table S1: Quantification of protein expression using Image J software.

Author Contributions: Conceptualization, S.T., C.C.B., J.K.-S.; methodology, S.T., C.C.B., J.K.-S.; validation, S.T. and A.M.W.; formal analysis, S.T.; investigation, S.T., A.M.W.; data curation, S.T.; writing-original draft preparation, S.T.; Writing-review and editing, S.T., A.M.W., C.C.B. and J.K.-S.; visualization, S.T.; supervision, C.C.B. and J.K.-S.; funding acquisition, J.K.-S. All authors have read and agreed to the published version of the manuscript.

Funding: The study was funded by University of Warwick, and National Science Foundation grants 2031614 and 1940169.

Acknowledgments: We would like to thank Mark Christian for providing 3T3-L1 cells.

Conflicts of Interest: The authors declare no conflict of interest. 


\section{References}

1. Smith, K.B.; Smith, M.S. Obesity Statistics. Prim. Care 2016, 43, 121-135. [CrossRef] [PubMed]

2. Schauer, P.R.; Kashyap, S.R.; Wolski, K.; Brethauer, S.A.; Kirwan, J.P.; Pothier, C.E.; Thomas, S.; Abood, B.; Nissen, S.E.; Bhatt, D.L. Bariatric surgery versus intensive medical therapy in obese patients with diabetes. N. Engl. J. Med. 2012, 366, 1567-1576. [CrossRef] [PubMed]

3. National Health Services. Causes: Obesity: National Health Services (NHS). Available online: https: //www.nhs.uk/conditions/obesity/causes/ (accessed on 6 June 2020).

4. Mordes, J.P.; Liu, C.; Xu, S. Medications for weight loss. Curr. Opin. Endocrinol. Diabetes. Obes. 2015, 22, 91-97. [CrossRef] [PubMed]

5. Kang, J.G.; Park, C.-Y. Anti-Obesity Drugs: A Review about Their Effects and Safety. Diabetes Metab. J. 2012, 36, 13-25. [CrossRef]

6. Soeliman, F.A.; Azadbakht, L. Weight loss maintenance: A review on dietary related strategies. J. Res. Med. Sci. Off. J. Isfahan Univ. Med. Sci. 2014, 19, 268-275.

7. Dansinger, M.L.; Gleason, J.A.; Griffith, J.L.; Selker, H.P.; Schaefer, E.J. Comparison of the Atkins, Ornish, Weight Watchers, and Zone diets for weight loss and heart disease risk reduction: A randomized trial. JAMA 2005, 293, 43-53. [CrossRef]

8. Blackburn, G.L.; Phillips, J.C.; Morreale, S. Physician's guide to popular low-carbohydrate weight-loss diets. Cleve. Clin. J. Med. 2001, 68, 761. [CrossRef]

9. Wan, R.; Ahmet, I.; Brown, M.; Cheng, A.; Kamimura, N.; Talan, M.; Mattson, M.P. Cardioprotective effect of intermittent fasting is associated with an elevation of adiponectin levels in rats. J. Nutr. Biochem. 2010, 21, 413-417. [CrossRef]

10. Anson, R.M.; Guo, Z.; De Cabo, R.; Iyun, T.; Rios, M.; Hagepanos, A.; Ingram, D.K.; Lane, M.A.; Mattson, M.P. Intermittent fasting dissociates beneficial effects of dietary restriction on glucose metabolism and neuronal resistance to injury from calorie intake. Proc. Natl. Acad. Sci. USA 2003, 100, 6216-6220. [CrossRef]

11. Brehm, B.J.; Seeley, R.J.; Daniels, S.R.; D’Alessio, D.A. A randomized trial comparing a very low carbohydrate diet and a calorie-restricted low fat diet on body weight and cardiovascular risk factors in healthy women. J. Clin. Endocrinol. Metab. 2003, 88, 1617-1623. [CrossRef]

12. Henry, R.R.; Wiest-Kent, T.A.; Scheaffer, L.; Kolterman, O.G.; Olefsky, J.M. Metabolic consequences of very-low-calorie diet therapy in obese non-insulin-dependent diabetic and nondiabetic subjects. Diabetes 1986, 35, 155-164. [CrossRef] [PubMed]

13. Baker, S.; Jerums, G.; Proietto, J. Effects and clinical potential of very-low-calorie diets (VLCDs) in type 2 diabetes. Diabetes Res. Clin. Pract. 2009, 85, 235-242. [CrossRef]

14. Delbridge, E.; Proietto, J. State of the science: VLED (Very Low Energy Diet) for obesity. Asia Pac. J. Clin. Nutr. 2006, 15, 49-54. [PubMed]

15. Kim, M.J.; Hwang, J.H.; Ko, H.J.; Na, H.B.; Kim, J.H. Lemon detox diet reduced body fat, insulin resistance, and serum hs-CRP level without hematological changes in overweight Korean women. Nutr. Res. 2015, 35, 409-420. [CrossRef]

16. Lu, Y.; Xi, W.; Ding, X.; Fan, S.; Zhang, Y.; Jiang, D.; Li, Y.; Huang, C.; Zhou, Z. Citrange fruit extracts alleviate obesity-associated metabolic disorder in high-fat diet-induced obese C57BL/6 mouse. Int. J. Mol. Sci. 2013, 14, 23736-23750. [CrossRef]

17. Estaquio, C.; Castetbon, K.; Kesse-Guyot, E.; Bertrais, S.; Deschamps, V.; Dauchet, L.; Péneau, S.; Galan, P.; Hercberg, S. The French National Nutrition and Health Program score is associated with nutritional status and risk of major chronic diseases. J. Nutr. 2008, 138, 946-953. [CrossRef] [PubMed]

18. Liu, S.; Serdula, M.; Janket, S.-J.; Cook, N.R.; Sesso, H.D.; Willett, W.C.; Manson, J.E.; Buring, J.E. A prospective study of fruit and vegetable intake and the risk of type 2 diabetes in women. Diabetes Care 2004, 27, 2993-2996. [CrossRef]

19. Coelho, R.C.L.A.; Hermsdorff, H.H.M.; Bressan, J. Anti-inflammatory properties of orange juice: Possible favorable molecular and metabolic effects. Plant Foods Hum. Nutr. 2013, 68, 1-10. [CrossRef]

20. Mollace, V.; Sacco, I.; Janda, E.; Malara, C.; Ventrice, D.; Colica, C.; Visalli, V.; Muscoli, S.; Ragusa, S.; Muscoli, C.; et al. Hypolipemic and hypoglycaemic activity of bergamot polyphenols: From animal models to human studies. Fitoterapia 2011, 82, 309-316. [CrossRef] 
21. Dow, C.A.; Going, S.B.; Chow, H.-H.S.; Patil, B.S.; Thomson, C.A. The effects of daily consumption of grapefruit on body weight, lipids, and blood pressure in healthy, overweight adults. Metabolism. 2012, 61, 1026-1035. [CrossRef]

22. Aptekmann, N.P.; Cesar, T.B. Long-term orange juice consumption is associated with low LDL-cholesterol and apolipoprotein B in normal and moderately hypercholesterolemic subjects. Lipids Health Dis. 2013, 12, 119. [CrossRef] [PubMed]

23. Oboh, G.; Bello, F.O.; Ademosun, A.O.; Akinyemi, A.J.; Adewuni, T.M. Antioxidant, hypolipidemic, and anti-angiotensin-1-converting enzyme properties of lemon (Citrus limon) and lime (Citrus aurantifolia) juices. Comp. Clin. Path. 2015, 24, 1395-1406. [CrossRef]

24. Tejpal, S.; Sanghera, N.; Manoharan, V.; Planas-Iglesias, J.; Myler, K.; Klein-Seetharaman, J. Towards personalised molecular feedback for weight loss. BMC Obes. 2019, 6, 20. [CrossRef] [PubMed]

25. Tejpal, S.; Bastie, C.; Seetharaman, J.K. Lemon Juice: A potential source of Angiotensin Converting Enzyme antagonism for weight loss and insulin resistance. Proc. Nutr. Soc. 2018, 77, E213. [CrossRef]

26. Reaven, G.M. Insulin resistance: The link between obesity and cardiovascular disease. Med. Clin. N. Am. 2011, 95, 875-892. [CrossRef]

27. Hill, J.O.; Peters, J.C. Biomarkers and functional foods for obesity and diabetes. Br. J. Nutr. 2002, 88, S213-S218. [CrossRef]

28. Wilcox, G. Insulin and insulin resistance. Clin. Biochem. Rev. 2005, 26, 19-39.

29. Atkinson, B.J.; Griesel, B.A.; King, C.D.; Josey, M.A.; Olson, A.L. Moderate GLUT4 overexpression improves insulin sensitivity and fasting triglyceridemia in high-fat diet-fed transgenic mice. Diabetes 2013, 62, 2249-2258. [CrossRef]

30. Garvey, W.T.; Maianu, L.; Huecksteadt, T.P.; Birnbaum, M.J.; Molina, J.M.; Ciaraldi, T.P. Pretranslational suppression of a glucose transporter protein causes insulin resistance in adipocytes from patients with non-insulin-dependent diabetes mellitus and obesity. J. Clin. Investig. 1991, 87, 1072-1081. [CrossRef]

31. Ikemoto, S.; Thompson, K.S.; Takahashi, M.; Itakura, H.; Lane, M.D.; Ezaki, O. High fat diet-induced hyperglycemia: Prevention by low level expression of a glucose transporter (GLUT4) minigene in transgenic mice. Proc. Natl. Acad. Sci. USA 1995, 92, 3096-3099. [CrossRef]

32. Abel, E.D.; Peroni, O.; Kim, J.K.; Kim, Y.-B.; Boss, O.; Hadro, E.; minnemann, T.; Shulman, G.I.; Kahn, B.B. Adipose-selective targeting of the GLUT4 gene impairs insulin action in muscle and liver. Nature 2001, 409, 729-733. [CrossRef] [PubMed]

33. Garin-Shkolnik, T.; Rudich, A.; Hotamisligil, G.S.; Rubinstein, M. FABP4 attenuates PPAR $\gamma$ and adipogenesis and is inversely correlated with PPAR $\gamma$ in adipose tissues. Diabetes 2014, 63, 900-911. [CrossRef] [PubMed]

34. Queipo-Ortuño, M.I.; Escoté, X.; Ceperuelo-Mallafré, V.; Garrido-Sanchez, L.; Miranda, M.; Clemente-Postigo, M.; Pérez-Pérez1, R.; Peral, B.; Cardona, F.; Fernández-Real, J.M.; et al. FABP4 dynamics in obesity: Discrepancies in adipose tissue and liver expression regarding circulating plasma levels. PLoS ONE 2012, 7, e48605. [CrossRef] [PubMed]

35. Duncan, R.E.; Ahmadian, M.; Jaworski, K.; Sarkadi-Nagy, E.; Sul, H.S. Regulation of lipolysis in adipocytes. Annu. Rev. Nutr. 2007, 27, 79-101. [CrossRef] [PubMed]

36. Carmen, G.-Y.; Víctor, S.-M. Signalling mechanisms regulating lipolysis. Cell. Signal. 2006, 18, 401-408. [CrossRef]

37. Miyoshi, H.; Perfield, J.W., II; Obin, M.S.; Greenberg, A.S. Adipose triglyceride lipase regulates basal lipolysis and lipid droplet size in adipocytes. J. Cell. Biochem. 2008, 105, 1430-1436. [CrossRef] [PubMed]

38. Stasiakowa, L. Sodium excretion in obese adolescents. Pol. Med. J. 1968, 7, 1344-1356.

39. Wang, P.; Holst, C.; Andersen, M.R.; Astrup, A.; Bouwman, F.G.; van Otterdijk, S.; Wodzig, W.K.W.H.; Van Baak, M.A.; Larsen, T.M.; Jebb, S.A.; et al. Blood profile of proteins and steroid hormones predicts weight change after weight loss with interactions of dietary protein level and glycemic index. PLoS ONE 2011, 6, e1677.

40. Eriksson, U.; Danilczyk, U.; Penninger, J.M. Just the beginning: Novel functions for angiotensin-converting enzymes. Curr. Biol. 2002, 12, R745-R752. [CrossRef]

41. Tejpal, S.; Sanghera, N.; Manoharan, V.; Planas-Iglesias, J.; Klein-Seetharaman, J. A marker for personalised feedback on dieting: Angiotensin Converting Enzyme. Proc. Nutr. Soc. 2019, 78, E44. [CrossRef] 
42. Pan, Y.-H.; Wang, M.; Huang, Y.-M.; Wang, Y.-H.; Chen, Y.-L.; Geng, L.-J.; Zhang, X.-X.; Zhao, H.-L. ACE Gene I/D Polymorphism and Obesity in 1,574 Patients with Type 2 Diabetes Mellitus. Dis. Markers 2016, 2016, 7420540. [CrossRef] [PubMed]

43. Patel, V.B.; Parajuli, N.; Oudit, G.Y. Role of angiotensin-converting enzyme 2 (ACE2) in diabetic cardiovascular complications. Clin. Sci. 2014, 126, 471-482. [CrossRef]

44. Perticone, F.; Ceravolo, R.; Iacopino, S.; Cloro, C.; Ventura, G.; Maio, R.; Gulletta, E.; Perrotti, N.; Mattioli, P.L. Relationship between Angiotensin-Converting Enzyme Gene Polymorphism and Insulin Resistance in Never-Treated Hypertensive Patients. J. Clin. Endocrinol. Metab. 2001, 86, 172-178. [CrossRef] [PubMed]

45. Messerli, F.H.; Bangalore, S.; Bavishi, C.; Rimoldi, S.F. Angiotensin-Converting Enzyme Inhibitors in Hypertension: To Use or Not to Use? J. Am. Coll. Cardiol. 2018, 71, 1474-1482. [CrossRef] [PubMed]

46. Jones, B.H.; Standridge, M.K.; Moustaid, N. Angiotensin II increases lipogenesis in 3T3-L1 and human adipose cells. Endocrinology 1997, 138, 1512-1519. [CrossRef] [PubMed]

47. Darimont, C.; Vassaux, G.; Ailhaud, G.; Negrel, R. Differentiation of preadipose cells: Paracrine role of prostacyclin upon stimulation of adipose cells by angiotensin-II. Endocrinology 1994, 135, 2030-2036. [CrossRef]

48. Zebisch, K.; Voigt, V.; Wabitsch, M.; Brandsch, M. Protocol for effective differentiation of 3T3-L1 cells to adipocytes. Anal. Biochem. 2012, 425, 88-90. [CrossRef]

49. Sentandreu, M.A.; Toldrá, F. A fluorescence-based protocol for quantifying angiotensin-converting enzyme activity. Nat. Protoc. 2006, 1, 2423-2427. [CrossRef]

50. Guerrero, L.; Castillo, J.; Quiñones, M.; Garcia-Vallve, S.; Arola, L.; Pujadas, G.; Muguerza, B. Inhibition of Angiotensin-Converting Enzyme Activity by Flavonoids: Structure-Activity Relationship Studies. PLoS ONE 2012, 7, e49493. [CrossRef]

51. Storka, A.; Vojtassakova, E.; Mueller, M.; Kapiotis, S.; Haider, D.G.; Jungbauer, A.; Wolzt, M. Angiotensin inhibition stimulates PPAR $\gamma$ and the release of visfatin. Eur. J. Clin. Invest. 2008, 38, 820-826. [CrossRef]

52. Fujimura, A.; Ushijima, K.; Ando, H. Does the PPAR- $\gamma$-activating property of telmisartan provide a benefit in clinical practice? Hypertens. Res. 2013, 36, 183. [CrossRef] [PubMed]

53. Mackenzie, R.W.; Elliott, B.T. Akt/PKB activation and insulin signaling: A novel insulin signaling pathway in the treatment of type 2 diabetes. Diabetes. Metab. Syndr. Obes. 2014, 7, 55-64. [CrossRef]

54. Proestos, C.; Chorianopoulos, N.; Nychas, G.-J.E.; Komaitis, M. RP-HPLC analysis of the phenolic compounds of plant extracts. investigation of their antioxidant capacity and antimicrobial activity. J. Agric. Food Chem. 2005, 53, 1190-1195. [CrossRef] [PubMed]

55. Cimpan, G.; Gocan, S. Analysis of Medicinal Plants by Hplc: Recent Approaches. J. Liq. Chromatogr. Relat. Technol. 2002, 25, 2225-2292. [CrossRef]

56. Zhou, S.; Song, L.; Masschelein, J.; Sumang, F.A.M.; Papa, I.A.; Zulaybar, T.O.; Custodio, A.B.; Zabala, D.; Alcantara, E.P.; Santos, E.L.C.D.L.; et al. Pentamycin Biosynthesis in Philippine Streptomyces sS816: Cytochrome P450-Catalyzed Installation of the C-14 Hydroxyl Grou. ACS Chem. Biol. 2019, 14, 1305-1309.

57. Eisenmann, J.C.; Sarzynski, M.A.; Glenn, K.; Rothschild, M.; Heelan, K.A. ACE I/D genotype, adiposity, and blood pressure in children. Cardiovasc. Diabetol. 2009, 8, 14. [CrossRef] [PubMed]

58. Cooper, R.; McFarlane-Anderson, N.; Bennett, F.I.; Wilks, R.; Puras, A.; Tewksbury, D.; Ward, R.; Forrester, T. ACE, angiotensinogen and obesity: A potential pathway leading to hypertension. J. Hum. Hypertens. 1997, 11, 107-111. [CrossRef]

59. Yvan-Charvet, L.; Quignard-Boulangé, A. Role of adipose tissue renin-angiotensin system in metabolic and inflammatory diseases associated with obesity. Kidney Int. 2011, 79, 162-168. [CrossRef]

60. Mulvihill, E.E.; Burke, A.C.; Huff, M.W. Citrus Flavonoids as Regulators of Lipoprotein Metabolism and Atherosclerosis. Annu. Rev. Nutr. 2016, 36, 275-299. [CrossRef]

61. Choi, J.S.; Yokozawa, T.; Oura, H. Improvement of hyperglycemia and hyperlipemia in streptozotocin-diabetic rats by a methanolic extract of Prunus davidiana stems and its main component, prunin. Planta Med. 1991, 57, 208-211. [CrossRef]

62. Kern, P.A.; di Gregorio, G.; Lu, T.; Rassouli, N.; Ranganathan, G. Perilipin expression in human adipose tissue is elevated with obesity. J. Clin. Endocrinol. Metab. 2004, 89, 1352-1358. [CrossRef] [PubMed]

63. Van Der Merwe, M.-T.; Schlaphoff, G.P.; Crowther, N.J.; Boyd, I.H.; Gray, I.P.; Joffe, B.I.; Lonnroth, P.N. Lactate and Glycerol Release from Adipose Tissue in Lean, Obese, and Diabetic Women from South Africa. J. Clin. Endocrinol. Metab. 2001, 86, 3296-3303. [CrossRef] 
64. Watt, M.J.; Holmes, A.G.; Pinnamaneni, S.K.; Garnham, A.P.; Steinberg, G.R.; Kemp, B.E.; Febbraio, M.A. Regulation of HSL serine phosphorylation in skeletal muscle and adipose tissue. Am. J. Physiol. Metab. 2006, 290, E500-E508. [CrossRef] [PubMed]

65. Gholamnezhad, Z.; Mégarbane, B.; Rezaee, R. Molecular Mechanisms Mediating Adaptation to Exercise BT. In Physical Exercise for Human Health; Xiao, J., Ed.; Springer: Singapore, 2020; pp. 45-61.

66. Jayasooriya, A.P.; Mathai, M.L.; Walker, L.L.; Begg, D.P.; Denton, D.A.; Cameron-Smith, D.; Egan, G.; McKinley, M.J.; Rodger, P.D.; Sinclair, A.J.; et al. Mice lacking angiotensin-converting enzyme have increased energy expenditure, with reduced fat mass and improved glucose clearance. Proc. Natl. Acad. Sci. USA 2008, 105, 6531-6536. [CrossRef] [PubMed]

67. Premaratna, S.D.; Manickam, E.; Begg, D.P.; Rayment, D.J.; Hafandi, A.; Jois, M.; Cameron-Smith, D.; Weisinger, R.S. Angiotensin-converting enzyme inhibition reverses diet-induced obesity, insulin resistance and inflammation in C57BL/6J mice. Int. J. Obes. 2012, 36, 233-243. [CrossRef]

68. Velkoska, E.; Warner, F.J.; Cole, T.J.; Smith, I.; Morris, M.J. Metabolic effects of low dose angiotensin converting enzyme inhibitor in dietary obesity in the rat. Nutr. Metab. Cardiovasc. Dis. 2010, 20, 49-55. [CrossRef]

69. Santos, E.L.; Souza, K.D.P.; Da Silva, E.D.; Batista, E.C.; Martins, P.J.F.; D'Almeida, V.; Pesquero, J.B. Long term treatment with ACE inhibitor enalapril decreases body weight gain and increases life span in rats. Biochem. Pharmacol. 2009, 78, 951-958. [CrossRef]

70. Jordan, J.; Stinkens, R.; Jax, T.; Engeli, S.; Blaak, E.; May, M.; Havekes, B.; Schindler, C.; Albrecht, D.; Pal, P.; et al. Improved Insulin Sensitivity With Angiotensin Receptor Neprilysin Inhibition in Individuals with Obesity and Hypertension. Clin. Pharmacol. Ther. 2017, 101, 254-263. [CrossRef]

71. Moro, C.; Galitzky, J.; Sengenes, C.; Crampes, F.; Lafontan, M.; Berlan, M. Functional and Pharmacological Characterization of the Natriuretic Peptide-Dependent Lipolytic Pathway in Human Fat Cells. J. Pharmacol. Exp. Ther. 2004, 308, 984-992. [CrossRef]

72. Sengenès, C.; Berlan, M.; De Glisezinski, I.; Lafontan, M.; Galitzky, J. Natriuretic peptides: A new lipolytic pathway in human adipocytes. FASEB J. 2000, 14, 1345-1351. [CrossRef]

73. Sengenès, C.; Bouloumié, A.; Hauner, H.; Berlan, M.; Busse, R.; Lafontan, M.; Galitzky, J. Involvement of a cGMP-dependent Pathway in the Natriuretic Peptide-mediated Hormone-sensitive Lipase Phosphorylation in Human Adipocytes. J. Biol. Chem. 2004, 278, 48617-48626. [CrossRef] [PubMed]

74. Willenbrock, R.; Scheuermann, M.; Thibault, G.; Haass, M.; Höhnel, K.; Bohlender, J.; Luft, F.C.; Dietz, R. Angiotensin inhibition and atrial natriuretic peptide release after acute volume expansion in rats with aortocaval shunt. Cardiovasc. Res. 1999, 42, 733-742. [CrossRef]

75. Liu, D.; Ceddia, R.P.; Collins, S. Cardiac natriuretic peptides promote adipose 'browning' through mTOR complex-1. Mol. Metab. 2018, 9, 192-198. [CrossRef] [PubMed]

76. Kaisanlahti, A.; Glumoff, T. Browning of white fat: Agents and implications for beige adipose tissue to type 2 diabetes. J. Physiol. Biochem. 2019, 75, 1-10. [CrossRef] [PubMed]

77. Carpentier, A.C.; Blondin, D.P.; Virtanen, K.A.; Richard, D.; Haman, F.; Turcotte, É.E. Brown Adipose Tissue Energy Metabolism in Humans. Front. Endocrinol. 2018, 9, 447. [CrossRef] [PubMed]

78. Braun, K.; Oeckl, J.; Westermeier, J.; Li, Y.; Klingenspor, M. Non-adrenergic control of lipolysis and thermogenesis in adipose tissues. J. Exp. Biol. 2018, 221, jeb.165381. [CrossRef]

79. Tejpal, S.; Sanghera, N.; Manoharan, V.; Planas-Iglesias, J.; Bastie, C.C.; Klein-Seetharaman, J. Angiotensin Converting Enzyme (ACE): A Marker for Personalized Feedback on Dieting. Nutrients 2020, 12, 660. [CrossRef]

80. Han, L.-K.; Sumiyoshi, M.; Zheng, Y.-N.; Okuda, H.; Kimura, Y. Anti-obesity action of Salix matsudana leaves (Part 2). Isolation of anti-obesity effectors from polyphenol fractions of Salix matsudana. Phytother. Res. 2003, 17, 1195-1198. [CrossRef] [PubMed]

81. Zang, Y.; Zhang, L.; Igarashi, K.; Yu, C. The anti-obesity and anti-diabetic effects of kaempferol glycosides from unripe soybean leaves in high-fat-diet mice. Food Funct. 2015, 6, 834-841. [CrossRef] [PubMed]

82. Jorge, A.P.; Horst, H.; De Sousa, E.; Pizzolatti, M.G.; Silva, F.R.M.B. Insulinomimetic effects of kaempferitrin on glycaemia and on 14C-glucose uptake in rat soleus muscle. Chem. Biol. Interact. 2004, 149, 89-96. [CrossRef]

83. Borradaile, N.M.; De Dreu, L.E.; Huff, M.W. Inhibition of net HepG2 cell apolipoprotein B secretion by the citrus flavonoid naringenin involves activation of phosphatidylinositol 3-kinase, independent of insulin receptor substrate-1 phosphorylation. Diabetes 2003, 52, 2554-2561. [CrossRef] [PubMed] 
84. Lee, S.H.; Park, Y.; Bae, K.; Bok, S.H.; Kwon, Y.; Lee, E.; Choi, M.-S. Cholesterol-lowering activity of naringenin via inhibition of 3-hydroxy-3-methylglutaryl coenzyme A reductase and acyl coenzyme A: Cholesterol acyltransferase in rats. Ann. Nutr. Metab. 1999, 43, 173-180. [CrossRef] [PubMed]

85. Mulvihill, E.E.; Assini, J.M.; Lee, J.K.; Allister, E.M.; Sutherland, B.G.; Koppes, J.B.; Sawyez, C.G.; Edwards, J.Y.; Telford, D.E.; Charbonneau, A.; et al. Nobiletin attenuates VLDL overproduction, dyslipidemia, and atherosclerosis in mice with diet-induced insulin resistance. Diabetes 2011, 60, 1446-1457. [CrossRef] [PubMed]

86. Burke, A.C.; Sutherland, B.G.; Telford, D.E.; Morrow, M.R.; Sawyez, C.G.; Edwards, J.Y.; Drangova, M.; Huff, M.W. Intervention with citrus flavonoids reverses obesity and improves metabolic syndrome and atherosclerosis in obese Ldlr(-/-) mice. J. Lipid Res. 2018, 59, 1714-1728. [CrossRef]

87. Kim, H.K.; Jeong, T.-S.; Lee, M.-K.; Park, Y.B.; Choi, M.-S. Lipid-lowering efficacy of hesperetin metabolites in high-cholesterol fed rats. Clin. Chim. Acta. 2003, 327, 129-137. [CrossRef]

88. Fukuchi, Y.; Hiramitsu, M.; Okada, M.; Hayashi, S.; Nabeno, Y.; Osawa, T.; Naito, M. Lemon Polyphenols Suppress Diet-induced Obesity by Up-Regulation of mRNA Levels of the Enzymes Involved in beta-Oxidation in Mouse White Adipose Tissue. J. Clin. Biochem. Nutr. 2008, 43, 201-209. [CrossRef]

89. Assini, J.M.; Mulvihill, E.E.; Huff, M.W. Citrus flavonoids and lipid metabolism. Curr. Opin. Lipidol. 2013, 24, 34-40. [CrossRef]

90. Rizza, S.; Muniyappa, R.; Iantorno, M.; Kim, J.-A.; Chen, H.; Pullikotil, P.; Senese, N.; Tesauro, M.; Lauro, D.; Cardillo, C.; et al. Citrus polyphenol hesperidin stimulates production of nitric oxide in endothelial cells while improving endothelial function and reducing inflammatory markers in patients with metabolic syndrome. J. Clin. Endocrinol. Metab. 2011, 96, E782-E792. [CrossRef]

91. Ghanim, H.; Sia, C.L.; Upadhyay, M.; Upadhyay, M.; Korzeniewski, K.; Viswanathan, P.; Abuaysheh, S.; Mohanty, P.; Dandona, P. Orange juice neutralizes the proinflammatory effect of a high-fat, high-carbohydrate meal and prevents endotoxin increase and Toll-like receptor expression. Am. J. Clin. Nutr. 2010, 91, 940-949. [CrossRef]

92. Nakajima, V.M.; Macedo, G.A.; Macedo, J.A. Citrus bioactive phenolics: Role in the obesity treatment. LWT Food Sci. Technol. 2014, 59, 1205-1212. [CrossRef]

93. Ono, E.; Inoue, J.; Hashidume, T.; Shimizu, M.; Sato, R. Anti-obesity and anti-hyperglycemic effects of the dietary citrus limonoid nomilin in mice fed a high-fat diet. Biochem. Biophys. Res. Commun. 2011, 410, 677-681. [CrossRef] [PubMed]

94. Maruyama, T.; Miyamoto, Y.; Nakamura, T.; Tamai, Y.; Okada, H.; Sugiyama, E.; Nakamura, T.; Itadani, H.; Tanaka, K. Identification of membrane-type receptor for bile acids (M-BAR). Biochem. Biophys. Res. Commun. 2002, 298, 714-719. [CrossRef]

95. Kwon, E.-Y.; Choi, M.-S. Dietary Eriodictyol Alleviates Adiposity, Hepatic Steatosis, Insulin Resistance, and Inflammation in Diet-Induced Obese Mice. Int. J. Mol. Sci. 2019, 20, 1227. [CrossRef] [PubMed]

(C) 2020 by the authors. Licensee MDPI, Basel, Switzerland. This article is an open access article distributed under the terms and conditions of the Creative Commons Attribution (CC BY) license (http://creativecommons.org/licenses/by/4.0/). 